\title{
Boosting toxic protein biosynthesis: transient in vivo inactivation of engineered bacterial alkaline phosphatase
}

Natalia Krawczun, Marta Bielawa, Kasjan Szemiako, Beata Łubkowska, Ireneusz Sobolewski, Agnieszka Zylicz-Stachula and Piotr M. Skowron* ${ }^{*}$

\begin{abstract}
Background: The biotechnology production of enzymes is often troubled by the toxicity of the recombinant products of cloned and expressed genes, which interferes with the recombinant hosts' metabolism. Various approaches have been taken to overcome these limitations, exemplified by tight control of recombinant genes or secretion of recombinant proteins. An industrial approach to protein production demands maximum possible yields of biosynthesized proteins, balanced with the recombinant host's viability. Bacterial alkaline phosphatase (BAP) from Escherichia coli (E. coli) is a key enzyme used in protein/antibody detection and molecular cloning. As it removes terminal phosphate from DNA, RNA and deoxyribonucleoside triphosphates, it is used to lower self-ligated vectors' background. The precursor enzyme contains a signal peptide at the $\mathrm{N}$-terminus and is secreted to the E. coli periplasm. Then, the leader is clipped off and dimers are formed upon oxidation.
\end{abstract}

Results: We present a novel approach to phoA gene cloning, engineering, expression, purification and reactivation of the transiently inactivated enzyme. The recombinant bap gene was modified by replacing a secretion leader coding section with a $\mathrm{N}$-terminal His6-tag, cloned and expressed in $E$. coli in a $P_{B A D}$ promoter expression vector. The gene expression was robust, resulting in accumulation of His6-BAP in the cytoplasm, exceeding 50\% of total cellular proteins. The His6-BAP protein was harmless to the cells, as its natural toxicity was inhibited by the reducing environment within the E. coli cytoplasm, preventing formation of the active enzyme. A simple protocol based on precipitation and immobilized metal affinity chromatography (IMAC) purification yielded homogeneous protein, which was reactivated by dialysis into a redox buffer containing reduced and oxidized sulfhydryl group compounds, as well as the protein structure stabilizing cofactors $\mathrm{Zn}^{2+}, \mathrm{Mg}^{2+}$ and phosphate. The reconstituted His6-BAP exhibited high activity and was used to develop an efficient protocol for all types of DNA termini, including problematic ones (blunt, 3'-protruding).

Conclusions: The developed method appears well suited for the industrial production of ultrapure BAP. Further, the method of transient inactivation of secreted toxic enzymes by conducting their biosynthesis in an inactive state in the cytoplasm, followed by in vitro reactivation, can be generally applied to other problematic proteins.

${ }^{*}$ Correspondence: piotr.skowron@ug.edu.pl

Department of Molecular Biotechnology, Faculty of Chemistry, University

of Gdansk, Wita Stwosza 63, 80-308 Gdansk, Poland

\section{Background}

Alkaline phosphatases (APS) (EC 3.1.3.1) are enzymes commonly found in nature, from bacteria to mammals [1]. The major function of E. coli BAP is to supply a source of inorganic phosphate when the environment is deprived of this compound by increasing the rate of diffusion of this compound into the cells and preventing 
phosphate from leaving the cells [2]. Once a phosphate group is clipped from a variety of organic compounds, it needs to enter the cytoplasm. Gram-negative E. coli bacteria contain a double membrane, where the outer membrane is decorated with porin proteins, thus allowing for the diffusion of charged molecules. Since phosphate is a highly charged anion, E. coli utilises a dedicated permease for the transport of this ion through its internal membrane - a nonpolar region essentially impermeable to charged molecules. Such a dedicated system was described as the phosphate-specific transport system (Pst system) [3, 4]. APS are almost exclusively homodimeric metalloproteins. Their common architecture includes each catalytic site containing three metal ions: two $\mathrm{Zn}^{2+}$ and one $\mathrm{Mg}^{2+}[5,6]$. Furthermore, they require the adoption of a catalytically active conformation facilitated by disulfide bridges, among others. In the fully active, dimeric BAP, $\mathrm{Zn}^{2+}$ occupies active sites $\mathrm{A}$ and $\mathrm{B}$, and $\mathrm{Mg}^{2+}$ occupies site $\mathrm{C}$, thus the enzyme has the configuration ( $\mathrm{ZnAZnBMgC}) 2$. Four cysteine residues create disulfide bridges linking the two subunits and are essential for mature BAP dimer activity [7]. Apparently, a combination of factors, including strong interactions between amino acid (aa) side chains, stabilisation of the $3 \mathrm{D}$ active conformation by divalent $\mathrm{Zn}^{2+}$ and $\mathrm{Mg}^{2+}$, as well as the presence of disulfide bridges result in an unexpected thermal stability of BAP, vastly exceeding the temperature growth range of $E$. coli. The enzyme is active up to $80{ }^{\circ} \mathrm{C}$ and even undergoes reversible renaturation at $90^{\circ} \mathrm{C}$, thus a heating step could be used in enzyme purification $[5,8]$. This thermostability may play a role in the resistance of BAP to inactivation by harsh environmental conditions, present outside the cytosol. The enzymes exhibit wide substrate specificity, and catalyses: the hydrolysis of monoesters of phosphoric acid, including $5^{\prime}$ ends of DNA, RNA, nucleotides and a transphosphorylation reaction in the presence of high concentrations of phosphate acceptors. Moreover, it hydrolyses oxyphosphate monoesters $[9,10]$, as well as a variety of $O$ - and $S$-phosphorothioates [11-13], phosphoramidates [10], thiophosphates and phosphates [14, 15]. A minor activity of E. coli BAP-oxidation of phosphite to phosphate was also detected. Purified BAP catalysed the oxidation of phosphite with specific activities approx. 1000-fold lower than phosphate ester hydrolysis. Interestingly, BAP catalyses the oxidation phosphite to phosphate and $\mathrm{H}_{2}$, thus it can be considered a phosphite-dependent hydrogenase that has emerged as a result of evolution [16]. Thus far, BAP was purified as a native or recombinant enzyme from its natural location in the periplasmic space, by weakening the outer membrane of cells, using for example osmotic shock [17] or a mutant E. coli strain [18]. BAP is widely used in molecular cloning for the removal of $5^{\prime}$ phosphates from linearized vectors, detecting PCR products, primer labelling and immunoassays. In this study, we describe a successful alternative strategy for the cloning and high production of BAP with transiently inhibited activity and thus 'toxicity' to the recombinant $E$. coli host. The strategy includes the biosynthesis of the leaderless His6-tagged BAP in the E. coli cytoplasm, followed by purification and oxidation/renaturation of the enzyme in vitro. We also believe that the developed method will be useful for the biotechnology scale production of other periplasm residing proteins/enzymes.

\section{Materials and methods}

\section{Bacterial strains, plasmids, media and reagents}

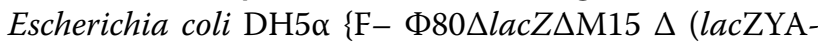
$\operatorname{arg\mathrm {F})} \mathrm{U} 169 \operatorname{rec} \mathrm{A} 1$ end $\mathrm{A} 1$ hsd $\mathrm{R} 17\left(\mathrm{r}_{\mathrm{K}-}, \mathrm{m}_{\mathrm{K}+}\right)$ phoA sup 44 $\lambda$-thi-1, gyrA96, relA1\} (Life Technologies, Gaithersburg, MD, USA) was used for electroporation and DNA propagation. E. coli $\mathrm{HB} 101\left\{\mathrm{~F}^{-} m c r \mathrm{~B} m r r h s d \mathrm{~S} 20\left(\mathrm{r}_{\mathrm{B}}^{-} \mathrm{m}_{\mathrm{B}}^{-}\right\}\right.$ recA13 leuB6 ara-14 proA2 lac $\mathrm{Y} 1$ gal $\mathrm{K} 2$ xyl-5 mtl-1 $r p s \mathrm{~L} 20\left(\mathrm{Sm}^{\mathrm{R}}\right) \operatorname{gln} \mathrm{V} 44 \lambda^{-}$\} (Thermo Fisher Scientific (MA, USA)/GIBCO BRL) was used for wt phoA gene source. Bacteria were grown in 2xYT medium [19]. For protein biosynthesis $E$. coli $\mathrm{TOP} 10\left\{\mathrm{~F}^{-}\right.$mcrA $\Delta$ (mrr-hsdRMSmorBC) $\phi 80$ lacZ $\Delta \mathrm{M} 15 \Delta$ lacX74 recA1 araD139 $\Delta$ (araleu)7697 gal $\mathrm{U}$ galK rpsL $\left(\mathrm{Str}^{\mathrm{R}}\right)$ end $\mathrm{A} 1$ nup $\mathrm{G} \lambda^{-}$\} was used (Invitrogen, CA, USA). The bacteria were cultivated in Terrific Broth (TB) medium [19], supplemented with ampicillin $(100 \mu \mathrm{g} / \mathrm{ml})$ and $0.2 \%$ maltose. Difco media components were obtained from Becton-Dickinson (Franklin Lakes, NJ). The proofreading Pwo Polymerase and DNA purification kits were from BLIRT (Gdansk, Poland). BsaI, NcoI and HindIII restriction endonucleases (REases) were from New England Biolabs (Ipswich, MA, USA). Protein standards, 100 bp DNA, 1 kb DNA markers, the cloning vector $\mathrm{pBADmycHisA}\left(\mathrm{Ap}^{\mathrm{R}}\right.$, colE1 ori, $P_{B A D}$ promoter) and Pierce ${ }^{\mathrm{TM}}$ BCA Protein Assay Kit were from Thermo Fisher Scientific. The DNA sequencing and PCR primer synthesis were conducted at Genomed (Warsaw, Poland). Ni Sepharose 6 Fast Flow chromatographic resin (GE Healthcare, cat. no GE175318-06), glutathione oxidized form (cat. no G4626), SIGMAFAST $^{\mathrm{TM}}$ Protease Inhibitor Tablets (cat. no S8820), SIGMAFAST $^{\mathrm{TM}}$ p-Nitrophenyl phosphate (pNPP) tablets (cat. no N2770), alkaline phosphatase from E. coli (cat. no P4252), reagents for Glycine with Zinc Enzymatic Assay and all the other chemicals were from Sigma-Aldrich (St. Louis, MO, USA).

\section{Cloning of modified his6-phoA gene}

Modified his6-phoA gene, encoding leaderless BAP protein was PCR amplified from the $E$. coli genome. The PCR reactions were performed in $50 \mu \mathrm{l}$ samples in a 
thermocycler (Applied Biosystems, CA, USA) and contained: $1 \times$ Pwo PCR Buffer, $0.2 \mathrm{mM}$ of each dNTP, $2 \mu \mathrm{M}$ of each primer, $100 \mathrm{ng}$ E. coli HB101 genomic DNA, $1 \mathrm{mM} \mathrm{MgCl}{ }_{2}$ and 1 unit of Pwo DNA polymerase. Mutagenic primers (Table 1) were used for PCR.

The introduced BsaI and HindIII restriction sites are underlined. DNA fragments introducing restriction sites, an aminopeptidase protection segment and His6-tag are written in capital letters. DNA fragments complementary to the leaderless wt $p h o A$ gene are in bold capital letters. Start and Stop codons are in italics. The PCR cycling profile was as follows: $94{ }^{\circ} \mathrm{C}$ for $3 \mathrm{~min}, 80^{\circ} \mathrm{C}$ for $20 \mathrm{~s}$ (addition of Pwo DNA polymerase), $94{ }^{\circ} \mathrm{C}$ for $30 \mathrm{~s}, 51^{\circ} \mathrm{C}$ for $30 \mathrm{~s}$, and $72{ }^{\circ} \mathrm{C}$ for $90 \mathrm{~s}$ (for 30 cycles); $72{ }^{\circ} \mathrm{C}$ for $3 \mathrm{~min}$. PCR products were purified and digested with $\mathrm{BsaI}$ and HindIII. A Type IIS REase - BsaI - in this case generated 4-nt cohesive ends compatible with NcoI cohesive ends. An arabinose-regulated expression vector $\mathrm{pBAD}$ mycHisA [20] was cut with NcoI and HindIII. Both the insert and the vector were separated using $1.2 \%$ agarose gel electrophoresis, purified and subjected to ligation using T4 DNA ligase at $16{ }^{\circ} \mathrm{C}$ overnight. The resulting DNA was used to transform E.coli DH5 $\alpha$ competent cells. After electroporation, the bacteria were plated onto 2xYT medium supplemented with ampicillin $(100 \mu \mathrm{g} / \mathrm{ml})$ and incubated at $28{ }^{\circ} \mathrm{C}$. The selection of positive bacterial clones was conducted by PCR screening of bacterial colonies using original mutagenic primers. After a preliminary analysis, plasmid DNAs isolated from the selected bacterial clones were subjected to DNA sequencing.

\section{Expression of the recombinant his6-phoA gene under $P_{B A D}$ promoter in E. coli}

The resulting positive bacterial clones were subjected to recombinant gene expression experiments. E. coli BL21(DE3) were electroporated with pBAD_BAP1 and mini-scale expression was performed by cultivation in $50 \mathrm{ml} \mathrm{TB}$ media supplemented with $100 \mu \mathrm{g} / \mathrm{ml}$ of ampicillin, at $28{ }^{\circ} \mathrm{C}$ with vigorous aeration. $P_{B A D}$ promoter

Table 1 DNA sequence of PCR primers used for his6-phoA gene cloning and engineering

\begin{tabular}{lll}
\hline Primer name & DNA sequence & Target \\
\hline FAlkPHisBsal & 5'-CCCCGGTCTCTCATG & wt phoA gene \\
& CCAATGTCTCAC & GenBank M29663.1 \\
& CACCA & protein id AAA24363.1 \\
& TCACCACCATAGAACA & \\
& CCAGAAATGCCT & \\
GT-3' & \\
RAlkPHindIII & 5'-CACGCCGGGCAAG & wt phoA gene \\
& CTTTTATTTCAGCC-3' & GenBank M29663.1 \\
& & protein id AAA24363.1 \\
\hline
\end{tabular}

induction was performed by the addition of $0.2 \%$ arabinose, when $\mathrm{A}_{600}$ reached 0.8 . The culture growth was continued for 19 hours (h) at $37{ }^{\circ} \mathrm{C}$. Bacterial pellets from both the control, non-induced and induced cultures were subjected to SDS/PAGE electrophoresis. The gels were analysed for the appearance of the expected band size of $\sim 40 \mathrm{kDa}$ and for colour reaction using the p-nitrophenol assay. The bacterial clones, efficiently expressing the his6-phoA gene, were selected for large-scale bacterial culture. Scaling up for biotechnology production included: (i) cultivation of $E$. coli TOP10[pBAD BAP1] in $0.5 \mathrm{~L}$ media containing $100 \mu \mathrm{g} / \mathrm{ml}$ ampicillin in a $5 \mathrm{~L}$ Erlenmeyer flasks at $37^{\circ} \mathrm{C}$ with vigorous aeration $(200 \mathrm{rpm})$ until $\mathrm{A}_{600}$ reached 0.5 and arabinose was added to $0.02 \%$ for the induction of the $P_{B A D}$ promoter. The flasks were further shaken for $18 \mathrm{~h}$; (ii) cultivation of E. coli TOP10[pBAD_BAP1] in 5 L TB media containing ampicillin at $100 \mu \mathrm{g} / \mathrm{ml}$ in a New Brunswick Scientific BioFlo1 15 fermenter at $28^{\circ} \mathrm{C}$ with vigorous aeration until $\mathrm{A}_{600}$ reached 1.0, then arabinose was added to $0.02 \%$ and further cultivation was conducted for $5 \mathrm{~h}$ at $37^{\circ} \mathrm{C}$.

\section{Purification and reactivation of the recombinant His6-BAP enzyme}

The recombinant His6-BAP purification procedure employed a simple protocol, which included: $(i)$ removal of nucleic acids and acidic proteins with polyethyleneimine (PEI); (ii) ammonium sulphate fractionation and (iii) metal affinity purification using Ni Sepharose 6 Fast Flow with immobilised $\mathrm{Ni}^{2+}$ ions.

\section{E. coli cells lysate preparation}

Recombinant E. coli TOP10[pBAD_BAP1] cells (2.5 g) were spun down and resuspended in $25 \mathrm{ml}$ cold lysis buffer $\left[30 \mathrm{mM}\right.$ Tris- $\mathrm{HCl} \mathrm{pH} 8.0$ at $20{ }^{\circ} \mathrm{C}, 30 \mathrm{mM} \mathrm{NaCl}$, $5 \%$ glycerol, $3 \mathrm{mM}$ 2-mercaptoethanol ( $\beta \mathrm{ME})$, protease inhibitors]. Lysozyme was added to $0.5 \mathrm{mg} / \mathrm{ml}$ and the suspension was incubated for $30 \mathrm{~min}$ at $4{ }^{\circ} \mathrm{C}$. Solid $\mathrm{NaCl}$ was added to a final $250 \mathrm{mM}$ concentration. Then, the initially lysed suspension was sonicated for $15 \times 1 \mathrm{~min}$ pulses with $1 \mathrm{~min}$ breaks at $0{ }^{\circ} \mathrm{C}$ (ice bath), until no increase of $\mathrm{A}_{280}$ was observed in samples taken after every sonication pulse. Finally the cell debris was spun down at $19,650 \times \mathrm{g}$ at $4{ }^{\circ} \mathrm{C}$ for $30 \mathrm{~min}$.

\section{PEI and ammonium sulphate fractionation}

To the supernatant, 10\% (v/v) PEI solution ( $\mathrm{pH} 7.5$ ) was slowly added until a final $1 \%(\mathrm{v} / \mathrm{v})$ solution was obtained and the suspension was stirred for $30 \mathrm{~min}$. The precipitated complexes of PEI-nucleic acids and PEI-acidic proteins were spun down at $19,650 \mathrm{x} \mathrm{g}$ at $4{ }^{\circ} \mathrm{C}$ for $30 \mathrm{~min}$. To the supernatant, solid ammonium sulphate was added at $0.5 \mathrm{~g} / \mathrm{ml}$ and stirred overnight at 
$4{ }^{\circ} \mathrm{C}$. Precipitated proteins were spun down at $19,650 \mathrm{x}$ $\mathrm{g}$ at $4{ }^{\circ} \mathrm{C}$ for $30 \mathrm{~min}$, the supernatant discarded and the protein pellet dissolved in $30 \mathrm{ml}$ of buffer $\mathrm{N}$ [50 mM K/ $\mathrm{PO}_{4} \mathrm{pH}$ 8.0, $20 \mathrm{mM}$ imidazole, $5 \%$ glycerol, $3 \mathrm{mM} \beta \mathrm{ME}$, $0.02 \%$ Triton $\mathrm{X}-100$, protease inhibitors]. The remaining undissolved proteins were centrifuged and discarded.

\section{Immobilized metal affinity purification (IMAC) using $\mathrm{Ni}$ Sepharose 6 Fast Flow}

Previous purification steps removed the bulk of the cellular contaminants from the crude His6-BAP-containing cell lysate. This allowed us to take full advantage of the high specificity of the immobilised $\mathrm{Ni}^{2+}$ interaction with His6-tagged recombinant BAP. The precipitated proteins after ammonium sulphate fractionation were dissolved in $30 \mathrm{ml}$ of $\mathrm{N} 1$ buffer $\left[20 \mathrm{mM} \mathrm{K} / \mathrm{PO}_{4} \mathrm{pH}\right.$ 8.0, $20 \mathrm{mM}$ imidazole, 5\% glycerol, $3 \mathrm{mM} \beta \mathrm{ME}, 0.02 \%$ Triton X-100; protease inhibitors] and undissolved proteins were removed by centrifugation. The preparation was loaded onto a $4 \mathrm{ml}$ column, packed with Ni Sepharose 6 Fast Flow, equilibrated in buffer N20 [20 mM K/PO $\mathrm{PH}_{4} \mathrm{pH}$ 8.0, $20 \mathrm{mM}$ imidazole, $0.5 \mathrm{M} \mathrm{NaCl}$, $5 \%$ glycerol, $3 \mathrm{mM} \beta \mathrm{ME}, 0.02 \%$ Triton $\mathrm{X}-100$; protease inhibitors], washed with $20 \mathrm{ml}$ of buffer N20, followed by washing with $20 \mathrm{ml}$ of buffer $\mathrm{N} 40\left[20 \mathrm{mM} \mathrm{K} / \mathrm{PO}_{4}\right.$ $\mathrm{pH}$ 8.0, $40 \mathrm{mM}$ imidazole, $0.5 \mathrm{M} \mathrm{NaCl}, 5 \%$ glycerol, $3 \mathrm{mM}$ ßME, $0.02 \%$ Triton X-100; protease inhibitors] and eluted with $12 \mathrm{ml}$ of buffer $\mathrm{N} 500\left[20 \mathrm{mM} \mathrm{K} / \mathrm{PO}_{4}\right.$ pH 8.0, $500 \mathrm{mM}$ imidazole, $0.5 \mathrm{M} \mathrm{NaCl}, 5 \%$ glycerol, $3 \mathrm{mM} \beta \mathrm{ME}, 0.02 \%$ Triton X-100; protease inhibitors]. The BAP purification protocol was scaled up for test purification from $50 \mathrm{~g}$ of the induced cells and the same results were obtained.

\section{His $_{6}-B A P$ enzymatic activity reactivation}

The purified preparation was dialysed overnight at $4{ }^{\circ} \mathrm{C}$ against two changes of $1 \mathrm{~L}$ reactivation-oxidation buffer [20 mM K/PO $\mathrm{PO}_{4} \mathrm{pH} 7.0,100 \mathrm{mM} \mathrm{KCl}, 0.2 \mathrm{mM} \mathrm{MgCl}$, $0.2 \mathrm{mM} \mathrm{ZnCl} 2,10 \%$ glycerol, $0.05 \%$ Tween $20,0.05 \%$ Nonidet 40, $5 \mathrm{mM}$ oxidized glutathione, $0.1 \mathrm{mM} \beta \mathrm{ME}]$. For the oxidation reaction, glutathione (oxidized form) is used from a fresh $0.5 \mathrm{M}$ stock in water (stored at $-80^{\circ} \mathrm{C}$ ). To the dialysed His6-BAP preparation, oxidized glutathione was added to increase its final concentration to $20 \mathrm{mM}$ and incubated overnight at $37^{\circ} \mathrm{C}$. The next day, the enzyme was dialyzed overnight at $4{ }^{\circ} \mathrm{C}$ against $1 \mathrm{~L}$ of storage buffer $\mathrm{S}\left[100 \mathrm{mM} \mathrm{KCl}, 0.1 \mathrm{mM} \mathrm{MgCl}_{2}, 0.1 \mathrm{mM}\right.$ $\mathrm{ZnCl}_{2}, 0.05 \%$ Tween $20,0.05 \%$ Nonidet $40,20 \mathrm{mM}$ Tris$\mathrm{HCl} \mathrm{pH} 7.0$ at $22{ }^{\circ} \mathrm{C}, 5 \mathrm{mM} \mathrm{K} / \mathrm{PO}_{4}$, pH 7.0, $5 \mathrm{mM}$ oxidized glutathione, $0.1 \mathrm{mM} \beta \mathrm{ME}, 50 \%$ glycerol] and stored at $-20{ }^{\circ} \mathrm{C}$.
Spectrophotometric assay for $\mathrm{His}_{6}$-BAP enzymatic activity The colorimetric assay of purified $\mathrm{His}_{6}$-BAP was conducted as based on the rate of release of p-nitrophenol from p-nitrophenyl phosphate by following the absorbance at $410 \mathrm{~nm}[5,21]$. One unit (U) was defined as the activity releasing $1 \mu \mathrm{M}$ p-nitrophenol per minute at $25^{\circ} \mathrm{C}$ in $3 \mathrm{ml}$ of reaction buffer containing: $1 \mathrm{mM} \mathrm{p}$-nitrophenyl phosphate, $1 \mathrm{M}$ Tris- $\mathrm{HCl}, \mathrm{pH} 8.0$ at $25^{\circ} \mathrm{C}$. The $\mathrm{U}$ calculation (specific activity) was as follows: $\mathrm{U} / \mathrm{mg}$ protein $={ }^{\wedge} \mathrm{A} /$ $\min \times 1000 / 1.62 \times 10,000 \times \mathrm{mg}$ enzyme/ml reaction [22]

\section{Enzymatic assay of alkaline phosphatase}

A comparative enzymatic 'Glycine with Zinc Assay' of purified $\mathrm{His}_{6}$-BAP and commercially available alkaline phosphatase from E. coli (Sigma-Aldrich) was conducted as based on the rate of release of p-nitrophenol from p-nitrophenyl phosphate by following the absorbance at $405 \mathrm{~nm}$. One unit will hydrolyze $1.0 \mu \mathrm{mol}$ of p-nitrophenyl phosphate per minute at $\mathrm{pH} 10.4$ at $37^{\circ} \mathrm{C}$. Final assay concentrations: In a $1.50 \mathrm{ml}$ reaction mix, the final concentrations are $87 \mathrm{mM}$ glycine, $0.90 \mathrm{mM}$ magnesium chloride, $0.87 \mathrm{mM}$ zinc chloride, $6.0 \mathrm{mM}$ p-nitrophenyl phosphate and 0.01-0.02 units of alkaline phosphatase. The U calculation (specific activity) was as follows: U/ml enzyme $=\frac{(\Delta \mathrm{A} 405 \mathrm{~nm} / \mathrm{min} \text { Test }-\Delta \mathrm{A} 405 \mathrm{~nm} / \mathrm{min} \text { Blank })(\text { volumeofassay })(\text { dilutionfactor })}{\text { (millimolar extinction coefficient of } \mathrm{p}-\text { nitrophenolat } 405 \mathrm{~nm})(\text { volume of enzyme used })}$ [23].

\section{His6-BAP functional assays}

To assess the His6-BAP capability to efficiently dephosphorylate DNA ends, assays were conducted in parallel with the highest quality commercial preparation that we could locate (Sigma, P4252). The Sigma BAP was sold as an ammonium sulphate precipitate suspension. $280 \mu \mathrm{l}$ suspension was carefully mixed, $100 \mu \mathrm{l}$ (35.7 U) was removed, centrifuged at $14000 \mathrm{x}$ g at $4{ }^{\circ} \mathrm{C}$ for $15 \mathrm{~min}$ and the supernatant was discarded. The Pellet was dissolved in $178.5 \mu \mathrm{l}$ of buffer A [ $200 \mathrm{mM} \mathrm{KCl}, 0.2 \mathrm{mM}$ $\mathrm{MgCl}_{2}, 0.2 \mathrm{mM} \mathrm{ZnCl}_{2}, 40 \mathrm{mM}$ Tris- $\mathrm{HCl} \mathrm{pH} 6.8$ at $22{ }^{\circ} \mathrm{C}$, $50 \%$ glycerol], obtaining an enzyme solution of concentration $0.2 \mathrm{U} / \mu \mathrm{l}$. Ten-fold serial dilutions of both Sigma BAP and His6-BAP were made in buffer A. Each reaction mixture in a $60 \mu \mathrm{l}$ volume of reaction buffer $\mathrm{R}[50 \mathrm{mM}$ Tris- $\mathrm{HCl} \mathrm{pH} 8.0$ at $\left.55^{\circ} \mathrm{C}, 1 \mathrm{mM} \mathrm{MgCl} 2,0.1 \mathrm{mM} \mathrm{ZnCl}_{2}\right]$ contained 1 pmol (app. $1.6 \mu \mathrm{g}$ ) of either SmaI-linearized or KpnI-linearized or EcoRI linearized pUC19 vector and a serial dilution of the enzymes. REase-digested pUC19 DNA was purified using a DNA Clean-Up kit prior to the dephosphorylation reaction. Following incubation at $55{ }^{\circ} \mathrm{C}$ for $45 \mathrm{~min}$, the reactions were terminated by purification using a DNA Clean-Up kit and self-ligated in a $30 \mu$ ligation buffer supplemented with 5\% PEG4000, using 10 Weiss $U$ of T4 DNA ligase. The reactions were terminated by heating at $70{ }^{\circ} \mathrm{C}$ for $5 \mathrm{~min}$ and the addition 
of SDS-containing loading dye/buffer and subjected to $1.0 \%$ agarose gel electrophoresis in TAE buffer. Gels were stained with ethidium bromide and photographed.

\section{Gel electrophoresis and protein concentration determination}

Agarose gels (1.0\%) for DNA analysis were prepared in TAE buffer [19]. The gels were visualized after staining with ethidium bromide using a $312 \mathrm{~nm}$ UV transilluminator or after staining with SYBR Green I using a $312 \mathrm{~nm}$ UV transilluminator and photographed with a SYBR Green gel stain photographic filter. SDS-PAGE electrophoresis of the proteins was in $10 \%$ polyacrylamide gels [19]. The protein concentrations were measured with a Pierce $^{\mathrm{TM}}$ BCA Protein Assay Kit according to the manufacturer's instructions.

\section{Results}

Rationale, design and cloning of a his6-phoA gene from $E$. coli

The rationale behind the general concept to obtain high overproduction of a toxic, recombinant protein was to biosynthesize it in a transiently inactive state: in the cytoplasm, which provides a reducing environment. This was to be followed by refolding in vitro under mild conditions in an oxidizing environment in the presence of a reaction product or substrate, redox buffer and cofactors, if applicable. In the example shown in this work, the modified His6-BAP was devoid of a secretion leader. Thus the produced truncated pre-protein was prevented from entering the periplasmatic space, which is required for disulfide bridge formation. Upon isolation from the cytoplasm of recombinant $E$. coli, the truncated, modified His6-BAP was to be restored to the enzymatically active state by dialysis into a buffer with $\mathrm{pH}$ and ionic strength simulating in vivo conditions. For this purpose, a mixture of oxidised and reduced sulfhydryl groupcontaining organic compounds, the protein structure stabilizing divalent ions cofactors $\mathrm{Zn}^{2+}$ and $\mathrm{Mg}^{2+}$ and dephosphorylation reaction product - phosphate was used. The native phoA $3^{\prime}$ gene fragment of $1353 \mathrm{bp}$, coding for a leaderless $\mathrm{C}$-terminal ORF and a Stop codon was PCR amplified with a mutagenic forward primer (62-nt) (Table 1), containing an overhang (42 nt) and mismatches, which introduced the BsaI restriction site. This arrangement removed the phoA leader-coding a $63 \mathrm{bp}$ (21 aa) $5^{\prime}$ region, replacing it with an in-frame $18 \mathrm{bp}$ segment coding for: 6 histidine residues for IMAC and a 4 aa segment MPMS, protecting the His6-tag from aminopeptidases in vivo and adding more immunogenic properties to the His6-tag for the possibility of using custom made antibodies (Fig. 1). The reverse mutagenic primer (27-nt) introduced a HindIII site. Following amplification, the reaction product was cut with BsaI and HindIII, purified and cloned into NcoI-HindIII cleaved arabinoseregulated pBADmycHisA expression vector in a perfect fusion with the vector's ATG codon. Since BsaI is a Type IIS REase, its 4-nt generated cohesive ends can be of any sequence. Thus they made CATG- $5^{\prime}$ to be compatible with the Ncol-generated cohesive ends. The resulting constructs were sequenced from both ORF ends and the pBAD_BAP1 clone was selected for expression experiments (Additional files 1, 2, 3, 4). The His6-BAP ORF was of $1383 \mathrm{bp}$, coding for a 460 aa fusion protein of molecular weight of $48.5 \mathrm{kDa}$ and theoretical pI of $5.89 \mathrm{com}$ pared to native, mature BAP (450 aa, $47.2 \mathrm{kDa}$, pI of 5.54) and wt BAP (471 aa, $49.5 \mathrm{kDa}$, pI of 5.81). The theoretical pIs were calculated using the ProtParam tool (https:// web.expasy.org/protparam/).

\section{Overproduction, purification and His6-BAP activity reconstitution in vitro}

In rich media and under intense aeration, the arabinose-induced recombinant $E$. coli TOP10 [pBAD BAP1] produced massive amounts of His6-BAP, being the predominant band on SDS-PAGE gels.

a BAP precursor

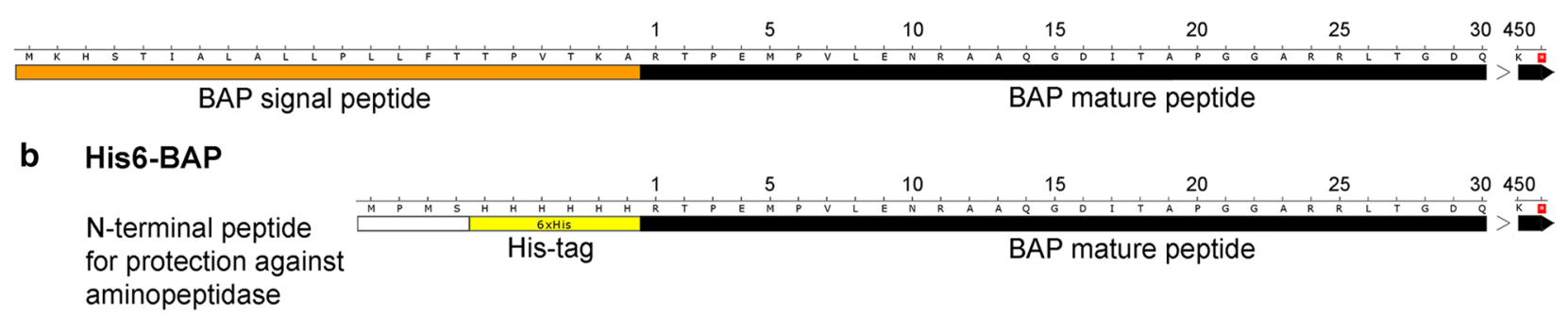

Fig. 1 Differences between the aa sequences of the wt BAP precursor and the engineered, leaderless His6-BAP polypeptide. The N-terminal aa sequence of the alkaline phosphatase precursor (GenBank M29663.1; protein id AAA24363.1). b The N-terminal aa sequence of the 48.4 kDa recombinant His6-BAP protein 
Cultivation of up to $20 \mathrm{~h}$ resulted in the highest His6BAP accumulation after 6 h (Fig. 2a). Figure 2a shows the time course of induction, where whole $E$. coli TOP10 [pBAD_BAP1] cells were lysed in denaturing buffer and loaded onto SDS-PAGE. Since the $4^{\text {th }} \mathrm{h}$ after induction, His6-BAP comprises the majority of cellular proteins. Thus, taken together the high biosynthesis level and His6-tag, a simple 4-step purification protocol was devised, comprising of: (i) sonication of entire cells, instead of extracting BAP from the periplasm; (ii) PEI precipitation of nucleic acids and acidic proteins; (iii) ammonium sulphate fractionation and (iv) IMAC. Purifications steps (ii) and (iii) removed the bulk of the cellular contaminants from the crude His6-BAP-containing cell extract. This allowed us to take full advantage of high specificity of the immobilised $\mathrm{Ni}^{2+}$ interaction with the His6-tagged recombinant His6-BAP. The interaction was strong, as $40 \mathrm{mM}$ imidazole-containing elution buffer eluted only trace amounts of the His6-BAP, while the bulk of the His6BAP eluted as a sharp peak with $500 \mathrm{mM}$ imidazole (Fig. 2b). Overall, the purification stages (ii)-(iv), each based on a different principle, were sufficient to obtain a homogeneous protein (Fig. 2b). The step (ii) of PEI precipitation of nucleic acids was also selected as beneficial from the stand point of application in genomic library preparations, as no E. coli DNA should be carried over with His6-BAP to be used for dephosphorylation. To increase yields and for protective purposes, glycerol and non-ionic detergents were added to block hydrophobic patches on the His6-BAP protein surface and prevent the protein from denaturation, aggregation and adhesion. Optionally, considering the reported thermostability of BAP $[5,8]$, a heat treatment step can be added. While heat treatment would not increase the apparent purity of the preparation, when examined on SDS-PAGE gel, for some special purposes it can be included into the presented purification protocol after ammonium sulphate fractionation and prior to IMAC (not shown). As judged by SDS-PAGE, fractions containing the highest His6-BAP content (Fig. 2b, lanes 6-10) were pooled and dialysed against the oxidizing buffer to promote the folding of the enzyme into an active state. Next, the enzyme was dialysed against storage buffer, containing 50\% glycerol and all the components of reactivation-oxidation buffer to maintain a stable redox environment. The buffered glycerol preparation was stored for over 4 years at $-20^{\circ} \mathrm{C}$ without an apparent loss of activity (not shown). The final preparation was assayed in a standard colorimetric assay using p-nitrophenyl phosphate $[5,21,22]$ in parallel with several available commercial preparations and their relative activities were compared. The His6-BAP exhibited a specific activity of approx. $80 \%$ of the commercially available preparations of the highest purity (not shown). Figure $2 \mathrm{c}$ shows the comparison of two BAP preparations: Sigma BAP (Fig. 2c, lane 1) and His6-BAP (Fig. 2c, lane 2), run in parallel as overloaded bands. The His6-BAP enzyme is stable, with minimal signs of degradation, when stored for over 4 years in a dedicated storage buffer with 50\% glycerol (Fig. 2c, lane 2). Due to the presence of the His6-tag, the His6-BAP has a higher molecular weight than Sigma BAP. The purity of both enzymes is very similar, with two more minor bands observed in the Sigma BAP preparation.

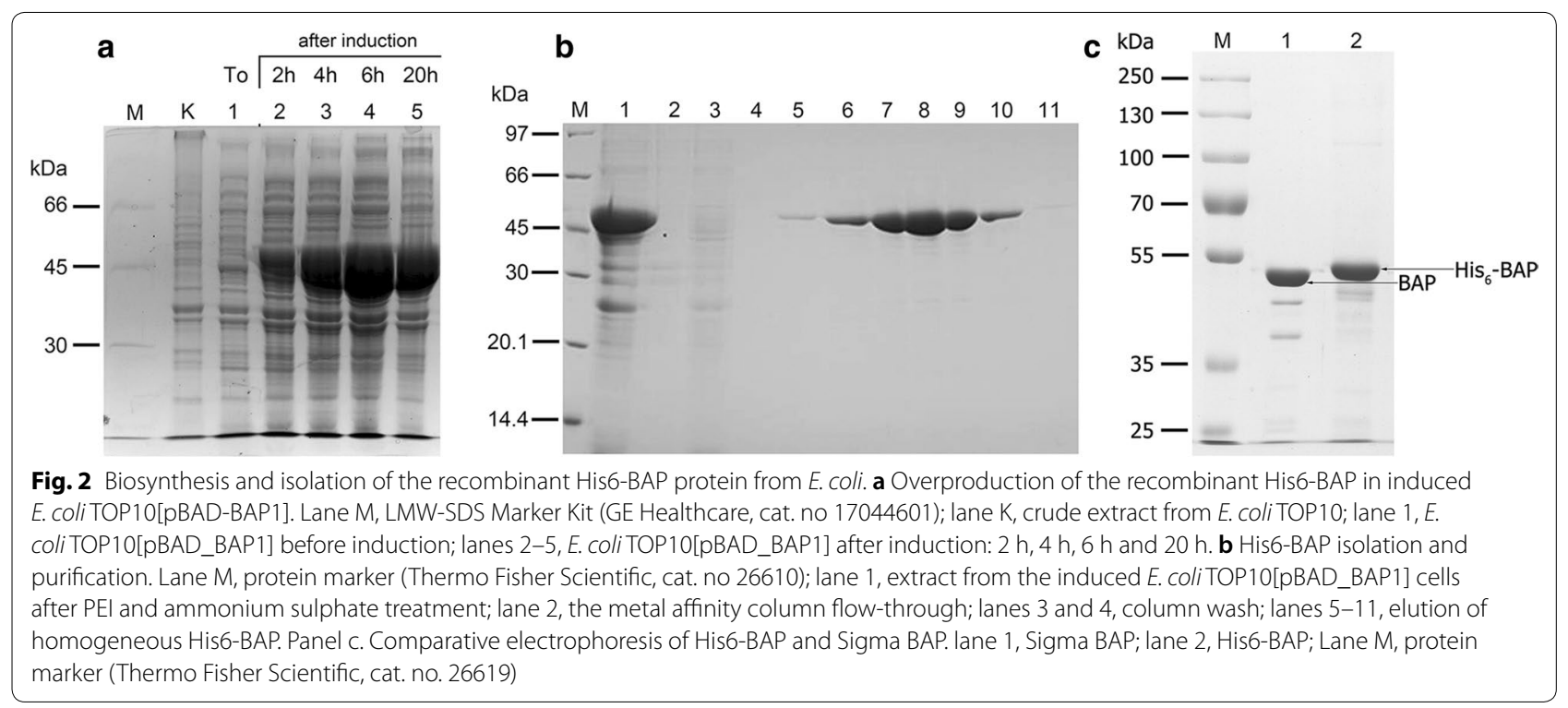


Fig. 3 Functional pUC19 vector dephosphorylation assays. a. EcoRI-linearized pUC19 DNA, subjected to dephosphorylation and self-ligation. Lane M, GeneRuler 1 kb DNA Ladder; lane K1, undigested pUC19 DNA; lane K2, EcoRI-linearized pUC19 DNA; lane LC (ligation control), non-dephosphorylated, selfligated EcoRI-linearized pUC19 DNA; lane 1, EcoRI-linearized pUC19 DNA dephosphorylated with 0.01 colorimetric $\mathrm{U}$ of His6-BAP and selfligated; lane 2, with $0.005 \mathrm{U}$; lane 3, with $0.0025 \mathrm{U}$; lane 4, with $00125 \mathrm{U}$. b EcoRI-linearized pUC19 DNA, subjected to dephosphorylation and self-ligation-fine-tuned His6-BAP concentrations. Lane M, GeneRuler 1 kb DNA Ladder; lane K1, undigested pUC19 DNA; lane K2, EcoRI-linearized pUC19 DNA; lane LC, non-dephosphorylated, selfligated EcoRI-linearized pUC19 DNA; lane 1, EcoRI-linearized pUC19 DNA dephosphorylated with 0.006 colorimetric $U$ of His6-BAP and selfligated; lane 2, with 0.005 $\mathrm{U}$; lane 3, with $0.004 \mathrm{U}$; lane 4, with $0.003 \mathrm{U}$; lane 5, with $0.002 \mathrm{U}$; lane 6, with 0.001 U. c Kpnl- or Smal-linearized pUC19 DNA, subjected to dephosphorylation and self-ligation. Lane M, GeneRuler 1 kb DNA Ladder; lanes K1, undigested pUC19 DNA; lane K3, Kpnl-linearized pUC19 DNA; lane LC, non-dephosphorylated, selfligated Kpnl-linearized pUC19 DNA; lane 1, Kpnl-linearized pUC19 DNA subjected to dephosphorylation with 0.05 colorimetric $U$ of His6-BAP and selfligation; lane 2, as in lane 1, except that $0.01 \cup$ His6-BAP were used; lane 3, $0.005 \mathrm{U}$; lane K4, Smal-linearized pUC19 DNA; lane LC, non-dephosphorylated, selfligated Smal-linearized pUC19 DNA; lane 4, Smal-linearized pUC19 DNA dephosphorylated with 0.05 colorimetric $\mathrm{U}$ of His6-BAP and selfligated; lane 5, with $0.01 \mathrm{U}$; lane 6, with $0.005 \mathrm{U}$

\section{Evaluation of His6-BAP performance in DNA dephosphorylation for molecular cloning}

One of the major purposes of this work was to provide large amounts of ultra-pure alkaline phosphatase for molecular cloning approaches, where thermolabile phosphatases do not perform well, namely, in preparation of blunt- and protruding $3^{\prime}$ termini of vector's DNA. For this purpose, we tested the His6-BAP in a vector dephosphorylation assay. Figure 3 shows the general cloning vector pUC19 cleavage/dephosphorylation/self-ligation assay. Clearly, His6-BAP efficiently dephosphorylates the vector's DNA. In the final range tested (from $5 \times 10^{-3}$ to $5 \times 10^{-2}$ colorimetric units) both Sigma BAP and His6BAP efficiently dephosphorylated KpnI-generated $3^{\prime}$ sticky ends and SmaI-generated blunt ends. For cloning, it is more convenient to use a DNA dephosphorylation activity unit, which is different than the definition of the activity unit used in the classical p-nitrophenyl phosphate assay. One should note that the phosphatase unit definition may vary, depending on manufacturer, but in general it is based on dephosphorylation of a set amount of DNA (such as $1 \mu \mathrm{g}$ ) or pmols of $5^{\prime}$ ends (such as $1 \mathrm{pmol}$ ) in a set reaction time, temperature and buffer composition. As $1 \mathrm{pmol}$ of DNA ends is a little over about $1 \mu \mathrm{g}$ of a $3 \mathrm{~kb}$ plasmid, these definitions are not far away from each other. Typically they use 10-30 min reaction time and $37^{\circ} \mathrm{C}$. For the purpose of this work we have adopted and modified the unit definition used by

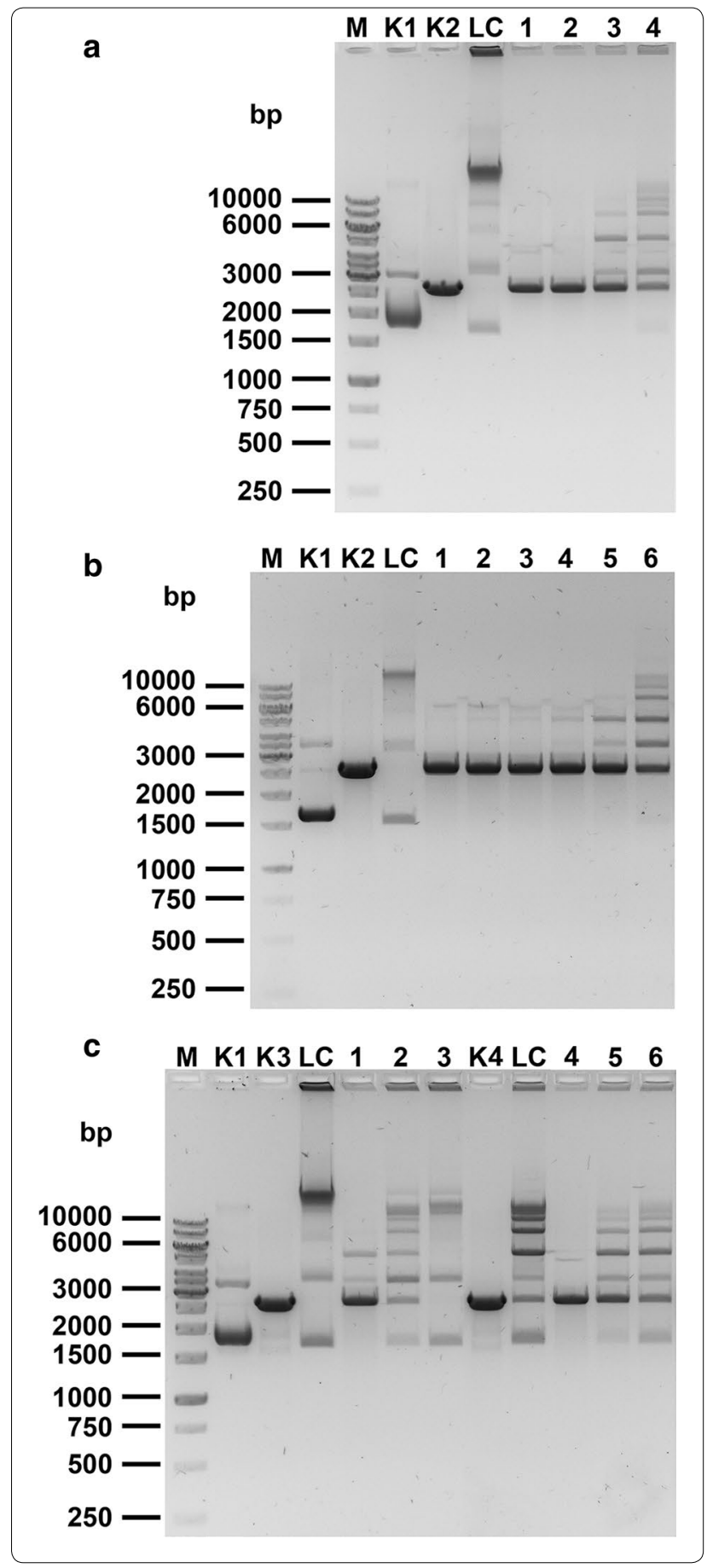

New England Biolabs [24]. Thus, after testing a number of variables (not shown) and considering the time effectiveness of cloning procedures, we selected a convenient practical 'cloning unit' for His6-BAP. The following conditions/definitions were used: dephosphorylation of $1 \mathrm{pmol}$ of SmaI-linearized $3 \mathrm{~kb}$ plasmid DNA for $45 \mathrm{~min}$ at $55{ }^{\circ} \mathrm{C}$, in the His6-BAP dephosphorylation buffer. 
Thus, one colorimetric unit corresponds to 20 DNA dephosphorylation units ('cloning units') for blunt/protruding 3' DNA termini as determined in Fig. 3c, lanes 1,4 . In the case of dephosphorylation of 5' protruding DNA termini, app. 10 times higher activity was observed (Fig. 3b, lanes 3-4). Even though the temperature of $55{ }^{\circ} \mathrm{C}$ was used, BAP thermostability allows for a further increase of the reaction temperature, if needed. When less enzyme is used, one can observe a mixture of ligated and non-ligated plasmid forms, indicating than only partial dephosphorylation was obtained. For the 3'-protruding, KpnI-linearized pUC19 DNA, very similar results were obtained, with slightly lower dephosphorylation efficiency, as faint ligated bands can be observed (Fig. 3c, lane 1). Thus, for a maximum reduction of the cloning background, we recommend to use an excess of His6-BAP, namely a minimum of 5-10 'cloning units' per $1 \mu \mathrm{g}$ of the linearized plasmid of approx. $3 \mathrm{~kb}$. The same results were obtained both for Sigma BAP and His6-BAP.

\section{Discussion}

Here, we propose a novel approach to the high level biosynthesis of toxic proteins by expressing them in an inactive state. This is followed by the use of an in vitro gentle reactivation method, not employing harsh protein unfolding compounds, such as guanidinium chloride, but rather based on a tertiary structure recovery stimulation by enzyme cofactors, reaction substrates, products and disulfide bridge formation in a buffer resembling in vivo conditions. Further, this apparently allowed correct arrangement of disulfide bridges formation. All of these factors help the distant, catalytically active, polypeptide segments to come together in a native arrangement. This is an alternative and/or complementary approach to our previous publications concerning the expression of high GC content toxic genes. In that work we designed, synthesized and cloned the entire recombinant genes, encoding thermophilic restriction endonucleases-methyltransferases (REases-MTases), 'toxic' to a recombinant E. coli host. For this purpose we used a modified 'one amino acid-one codon' optimization method combined with weighting toward low GC content codons. This approach allowed for a significant expression increase of a thermophile gene in the recombinant host [25]. Together with the post-optimization sequence scanning for mRNA secondary structures, codon clusters and the local codon environment, the final synthetic gene became ' $E$. coli friendly', allowing for a one-order of magnitude increase in taqIIRM gene expression. In another approach, we used a biased 'codon randomization' method, which besides ORF optimization, apparently sped up the translation kinetics, which proved to be critically important to allow recombinant TthHB101RM REase-MTase to fold into an active state [26]. All the above approaches, including His6-BAP, can be combined to efficiently biosynthesize secreted 'toxic' proteins from a thermophile or other bacteria/archaea with GC-rich genomes. As the expression of the wt phoA gene is induced in $E$. coli (when grown under phosphate-limiting conditions) and results in moderate production of BAP, it can be considered as already naturally 'optimized' with regard to codon usage context, mRNA sequence and structure among other factors. Thus there was no need for applying gene optimisation procedures to obtain a high expression level, when natural regulation of $p h o A$ gene was replaced by the vector's precisely regulated $P_{B A D}$ promoter [20], as we obtained in our hands as massive natural codon-containing gene expression as for best optimised. This system is approaching the levels of expression as known from highest robustness T7-lac promoter-containing expression vectors [27]. The native BAP gene, containing a secretion leader, was cloned previously into bacteriophage lambda and further subcloned into the pBR322 vector derivative $[28,29]$ and into a derivative of pBluescript-SK(-) vector [30]. Those constructs were not for overproduction and directed BAP into the periplasm. However, an interesting observations were made by others that concern $E$. coli BAP production [31] on overproduction of the cloned native BAP precursor, where formation of cytoplasmic inclusion bodies was observed. Accumulation of BAP precursor at a high rate indicates that its synthesis can be uncoupled from secretion [31]. It may also suggest, that the presence of leader secretion peptide in the BAP precursor impairs its folding, thus leading to the inclusion bodies formation and providing additional natural route of transient toxicity suppression. In contrast, we cloned the mature, leaderless BAP with added His6-tag. The recombinant His6-BAP was biosynthesized in the $E$. coli cytoplasm in an soluble, but inactive form, thus nontoxic. This allowed for massive biosynthesis, comprising over $50 \%$ of cellular proteins of the recombinant host. We believe that this strategy will be useful for biotechnology industry production. The isolation/purification is fairly straightforward, with only one chromatographic step on $\mathrm{Ni}^{2+}$-chelating metal affinity resin, proceeded by two rapid precipitation steps involving PEI and ammonium sulphate, yielding a homogeneous protein. Further, we developed a simplified and mild BAP reactivation protocol, based on oxidation of cysteines in the presence of correct fold-stimulating agents (in this case $\mathrm{Mg}^{2+}, \mathrm{Zn}^{2+}$, phosphate, detergents, physiological $\mathrm{pH}$ and salt concentration). While native (= secreted and purified from periplasm) BAP was subjected to denaturation and successful refolding into an active state previously, these approaches were based on harsh conditions, such as the use of concentrated solutions of guanidinium hydrochloride 
[32-34]. Further, in those previous works, concerning denaturation/renaturation of phosphatases, there were used natively matured enzymes, thus already containing disulfide bridges in correct arrangements [32-34]. The overproduction, purification and reactivation procedure of His6-BAP is easily scalable. We repeated the described procedure in various variants, using from $0.5 \mathrm{~g}$ up to $50 \mathrm{~g}$ of the induced bacterial cells. Comparative assays of the His6-BAP (conducted in parallel with the highest activity available commercially BAP preparation) showed that His6-BAP has essentially the same specific activity. Previously it was found that BAP is a thermostable enzyme in a mesophilic, cytoplasmatic environment [18]. This does not necessarily mean that there is an evolutionary relationship with 'truly' thermophilic enzymes, rather points to convergent protein structure evolution of mesophilic enzyme to withstand the harsher than cytoplasmatic conditions of an external environment. This feature can be exploited in adding an extra purification step to the His6-BAP protocol presented here, if desired for special application purposes. The thermal stability of BAP imposes linearized vector DNA purification upon dephosphorylation. Using other thermolabile phosphatases, such as calf intestinal phosphatase [35] or oceanic shrimp phosphatase [36], is convenient in DNA manipulations, as they can be heat-inactivated. However, high BAP thermostability may be of practical use in DNA manipulation methodologies in some applications, such as dephosphorylation of GC-rich blunt ends of DNA molecules, as DNA end 'breathing' at elevated temperatures makes $5^{\prime}$-phosphates more accessible to the enzyme.

\section{Conclusions}

1. E. coli phoA gene was engineered by removal of the secretion leader and its replacement by a His6-tag and cloned under the $P_{B A D}$ promoter control, which resulted in the cytoplasmatic biosynthesis of the recombinant His6-BAP.

2. A very high level of inactive His6-BAP overproduction was achieved as a result of combination of the strong $P_{B A D}$ promoter and transient suppression of His6-BAP toxicity by preventing essential disulfide bridge formation in the reducing cytoplasmatic environment.

3. A simple protocol of purification to homogeneity of His6-BAP, suitable for biotechnology production, was developed.

4. An in vitro His6-BAP activity reactivation protocol was developed, based on folding and gentle oxidation in redox buffer, supplemented with cofactors $\mathrm{Zn}^{2+}$,
$\mathrm{Mg}^{2+}$ ), reaction product (phosphate) and non-ionic detergents.

5. An efficient dephosphorylation protocol was developed for all types of DNA termini: blunt, $3^{\prime}$ protruding and $5^{\prime}$ protruding.

\section{Supplementary information}

Supplementary information accompanies this paper at https://doi. org/10.1186/s12934-020-01424-y.

Additional file 1. Nucleotide and aa sequences of the His6-BAP ORF. The genetic map was prepared using SnapGene software version 4.1 (http:// www.snapgene.com)

Additional file 2. Map of pBAD_BAP1.

Additional file 3. Map, nucleotide and aa sequences of the recombinant pBAD_BAP1 construct. The additional file was prepared using SnapGene software version 4.1 (http://www.snapgene.com).

Additional file 4. Nucleotide sequence of the recombinant pBAD_BAP1 construct.

\section{Acknowledgements}

Dr Patrick Groves is highly appreciated for critical review and English corrections.

\section{Authors' contributions}

PMS designed the engineering of the phoA gene, the experiments, coordinated their execution and drafted the manuscript. NK performed the experiments concerning cloning and expression of the his6-phoA gene. MB and NK conducted protein purification. KS and MB performed enzymatic assays. IS and $\mathrm{BL}$ conducted functional assays. AZS prepared figures, critically reviewed and formatted the manuscript. All authors read and approved the final manuscript.

Funding

This work was supported by Gdansk University, Chemistry Department fund DS 530-8645-D746-18 and TECHMATSTRATEG2/410747/11/NCBR/2019 grant to University of Gdansk, Faculty of Chemistry, Molecular Biotechnology Department.

Availability of data and materials

All the data needed to repeat experiments are present in the manuscript and supplementary files. His6-BAP clones are available upon request.

Ethics approval and consent to participate

All the authors approved the manuscript. No other ethical issues are present.

Competing interests

The authors declare that they have no competing interest.

Received: 10 June 2020 Accepted: 11 August 2020

Published online: 18 August 2020

\section{References}

1. Kim EE, Wyckoff HW. Reaction mechanism of alkaline phosphatase based on crystal structures. Two-metal ion catalysis. J Mol Biol. 1991;218(2):44964. https://doi.org/10.1016/0022-2836(91)90724-k.

2. Horiuchi T, Horiuchi S, Mizuno D. A possible negative feedback phenomenon controlling formation of alkaline phosphomonoesterase in Escherichia coli. Nature. 1959;183(4674):1529-30. https://doi.org/10.1038/18315 29b0. 
3. Rao NN, Torriani A. Molecular aspects of phosphate transport in Escherichia coli. Mol Microbiol. 1990;4(7):1083-90. https://doi. org/10.1111/j.1365-2958.1990.tb00682.x.

4. Willsky GR, Bennett RL, Malamy MH. Inorganic phosphate transport in Escherichia coli: involvement of two genes which play a role in alkaline phosphatase regulation. J Bacteriol. 1973;113(2):529-39.

5. Applebury ML, Coleman JE. Escherichia coli alkaline phosphatase Metal binding, protein conformation, and quaternary structure. J Biol Chem. 1969:244:308-18.

6. Coleman JE. Structure and mechanism of alkaline phosphatase. Annu Rev Biophys Biomol Struct. 1992;21:441-83. https://doi.org/10.1146/annur ev.bb.21.060192.002301.

7. Bosron WF, Anderson RA, Falk MC, Kennedy FS, Vallee BL. Effect of magnesium on the properties of zinc alkaline phosphatase. Biochemistry. 1977;16(4):610-4. https://doi.org/10.1021/bi00623a009.

8. Schlesinger MJ, Barrett $K$. The reversible dissociation of the alkaline phosphatase of Escherichia coli. I. Formation and reactivation of subunits. J Biol Chem. 1965;240(11):4284-92.

9. Fernley HN, Walker PG. Studies on alkaline phosphatase Transient-state and steady-state kinetics of Escherichia coli alkaline phosphatase. Biochem J. 1969;111(2):187-94. https://doi.org/10.1042/bj1110187.

10. Reid TW, Wilson IB. E. coli Alkaline Phosphatase. In: Boyer PD, editor. The Enzymes (3rd ed.). New York: Academic Press; 1971. p. 373-415. doi: doi. org/https://doi.org/10.1016/s1874-6047(08)60377-7.

11. Mushak P, Coleman J. Hydrolysis of a stable oxygen ester of phosphorothiotic acid by alkaline phosphatase. Biochemistry. 1972;11(2):201-5. https://doi.org/10.1021/bi00752a009.

12. Neumann $\mathrm{H}$. Substrate selectivity in the action of alkaline and acid phosphatases. J Biol Chem. 1968;234(18):4671-6.

13. Chlebowski JF, Coleman JE. Mechanisms of hydrolysis of O-phosphorothioates and inorganic thiophosphate by Escherichia coli alkaline phosphatase. J Biol Chem. 1974;249(22):7192-202.

14. Applebury ML, Johnson BP, Coleman JE. Phosphate binding to alkaline phosphatase. Metal ion dependence. J Biol Chem. 1970;245(19):4968-76.

15. Schwartz JH. The phosphorylation of alkaline phosphatase. Proc Natl Acad Sci USA. 1963:49:871-8. https://doi.org/10.1073/pnas.49.6.871.

16. Yang K, MetcalfWW. A new activity for an old enzyme: escherichia coli bacterial alkaline phosphatase is a phosphite-dependent hydrogenase. Proc Natl Acad Sci USA. 2004;101(21):7919-24. https://doi.org/10.1073/ pnas.0400664101.

17. Garen C, Levinthal A. A fine structure genetic and chemical study of the enzyme alkaline phosphatase of E coli. I. Purification and characterization of alkaline phosphatase. Biochim Biophys Acta. 1960;38:470-83. https:// doi.org/10.1016/0006-3002(60)91282-8.

18. Atlan D, Portalier R. Purification of extracellular alkaline phosphatase released by Escherichia coli excretory mutants. Appl Microbiol Biotechnol. 1987;26:318-22

19. Green MR, Sambrook J. Molecular Cloning: A Laboratory Manual. 4th ed. CSH NY: Cold Spring Harbor Laboratory Press; 2012.

20. Guzman LM, Belin D, Carson MJ, Beckwith J. Tight regulation, modulation, and high-level expression by vectors containing the arabinose $P_{B A D}$ promoter. J Bacteriol. 1995;177(14):4121-30. https://doi.org/10.1128/ jb.177.14.4121-4130.1995.

21. Torriani A. Influence of inorganic phosphate in the formation of phosphatases by Escherichia coli. Biochim Biophys Acta. 1960;38:490-9. https ://doi.org/10.1016/0006-3002(60)91281-6.

22. Worthington $K$, Worthington $V$. In: Worthington Enzyme Manual. Worthington Biochemical Corporation. 2011. http://www.worthington-bioch em.com/BAP/default.html. Accessed 6 Mar 2020

23. Bergmeyer, H.U., Grassl, M., and Walter, H.E. (1983) in Methods of Enzymatic Analysis, (Bergmeyer, H.U., ed) 3rd ed., Volume II, 269-270, Verlag Chemie, Deerfield Beach, FL.

24. New England Biolabs https://international.neb.com/proto cols/2013/06/10/protocol-for-dephosphorylation-of-5-ends-of-dnam0371\%20. Accessed 7 Mar 2020.

25. Zylicz-Stachula A, Zolnierkiewicz O, Sliwinska K, Jezewska-Frackowiak J, Skowron PM. Modified 'one amino acid-one codon' engineering of high GC content Taqll-coding gene from thermophilic Thermus aquaticus results in radical expression increase. Microb Cell Fact. 2014;13:7. https:// doi.org/10.1186/1475-2859-13-7.
26. Krefft D, Papkov A, Zylicz-Stachula A, Skowron PM. Thermostable proteins bioprocesses: The activity of restriction endonuclease-methyltransferase from Thermus thermophilus (RM.TthHB27I) cloned in Escherichia coli is critically affected by the codon composition of the synthetic gene. PLoS ONE. 2017;12:e0186633. https://doi.org/10.1371/journal.pone.0186633.

27. Rosenberg AH, Lade BN, Chui DS, Lin SW, Dunn JJ, Studier FW. Vectors for selective expression of cloned DNAs by T7 RNA polymerase. Gene. 1987;56(1):125-35. https://doi.org/10.1016/0378-1119(87)90165-x.

28. Yoda K, Kikuchi Y, Yamasaki M, Tamura G. Cloning of the structural gene of alkaline phosphatase of Escherichia coli K12. Agric Biol Chem. 1980;44(5):1213-4. https://doi.org/10.1080/00021369.1980.10864108.

29. Inouye $H$, Michaelis S, Wright A, Beckwith J. Cloning and restriction mapping of the alkaline phosphatase structural gene (phoA) of Escherichia coli and generation of deletion mutants in vitro. J Bacteriol. 1981;146(2):668-75.

30. Sone T, Wang CY. Microsomal amidases and carboxylesterases. In: Sipes IG, McQueen CA, Gandolfi AJ, Guengerich FP, editors. Comprehensive Toxicology: Biotransformation. New York: Pergamon Elsevier Science Ltd. 1997. p. 265-81.

31. Georgiou G, Telford JN, Shuler ML, Wilson DB. Localization of inclusion bodies in Escherichia coli overproducing beta-lactamase or alkaline phosphatase. Appl Environ Microbiol. 1986;52(5):1157-61. https://doi. org/10.1128/AEM.52.5.1157-1161.1986.

32. Sarkar SN, Ghosh N. Reversible unfolding of Escherichia coli alkaline phosphatase: active site can be reconstituted by a number of pathways. Arch Biochem Biophys. 1996;330(1):174-80. https://doi.org/10.1006/ abbi.1996.0239.

33. Ghosh N, Sarkar SN, Roy KB. Excess nucleoside triphosphates (or zinc) allow recovery of alkaline phosphatase activity following refolding under reducing conditions. Biochemistry. 1998;37(44):15542-7. https://doi. org/10.1021/bi972833g.

34. Dirnbach E, Steel DG, Gafni A. Proline isomerization is unlikely to be the cause of slow annealing and reactivation during the folding of alkaline phosphatase. J Biol Chem. 1999;274(8):4532-6. https://doi.org/10.1074/ jbc.274.8.4532.

35. Tabor S. Phosphatases and kinases. Curr Protoc Mol Biol. 2001;3(Unit3):10. https://doi.org/10.1002/0471142727.mb0310s00.

36. Ásgeirsson B, Hartemink R, Chlebowski JF. Alkaline phosphatase from Atlantic cod (Gadus morhua). Kinetic and structural properties which indicate adaptation to low temperatures. Comp Biochem Physiol B Biochem Mol Biol. 1995;110(2):315-29. https://doi.org/10.1016/03050491(94)00171-p.

\section{Publisher's Note}

Springer Nature remains neutral with regard to jurisdictional claims in published maps and institutional affiliations.

Ready to submit your research? Choose BMC and benefit from

- fast, convenient online submission

- thorough peer review by experienced researchers in your field

- rapid publication on acceptance

- support for research data, including large and complex data types

- gold Open Access which fosters wider collaboration and increased citations

- maximum visibility for your research: over $100 \mathrm{M}$ website views per year

At BMC, research is always in progress.

Learn more biomedcentral.com/submissions 